\title{
Effect of extracts and isolated compounds from Chresta scapigera on viability of Leishmania amazonensis and Trypanosoma cruzi
}

\author{
Elisandra Cristina Schinor ${ }^{1 *}$, Marcos José Salvador ${ }^{2,5}$, Elisabeth Mieko Furusho Pral ${ }^{3}$, Silvia Celina \\ Alfieri $^{3}$, Sérgio Albuquerque ${ }^{4}$, Diones Aparecida Dias ${ }^{1,5}$
}

\begin{abstract}
'Departamento de Química da Faculdade de Filosofia, Ciências e Letras de Ribeirão Preto, Universidade de São Paulo, ${ }^{2}$ Universidade do Vale do Paraíba, Instituto de Pesquisa e Desenvolvimento, ${ }^{3}$ Departamento de Parasitologia do Instituto de Ciências Biomédicas, Universidade de São Paulo, ${ }^{4}$ Departamento de Análises Clínicas, Toxicológicas e Bromatológicas da Faculdade de Ciências Farmacêuticas de Ribeirão Preto, Universidade de São Paulo,

${ }^{5}$ Departamento de Física e Química da Faculdade de Ciências Farmacêuticas de Ribeirão Preto,
\end{abstract}

Universidade de São Paulo

*Correspondence:

E. C. Schinor

Departamento de Física e Química

Faculdade de Ciências Farmacêuticas

de Ribeirão Preto

Universidade de São Paulo

Av. do Café, s/n

14040-903 - Ribeirão Preto - SP, Brasil

E-mail: ec.schinor@uol.com.br
Fractionation of bioactive crude extracts of Chresta scapigera led to the isolation of four triterpenes and five flavonoids, among them $\beta$-amyrin acetate (1), $11 \alpha, 12 \alpha$-oxidetaraxeryl acetate (2) and lupeol (3), as well as the flavonoids apigenin (6), kaempferol (7), crysoeriol (8) and luteolin (9) were active against Leishmania amazonensis amastigotes-like stages, while only the flavonoids (6), (7) and (9) showed toxicity towards bloods trypomastigote forms of Trypanosoma cruzi.

\author{
Uniterms \\ - Chresta scapigeral \\ trypanocidal activity \\ - Flavonoids \\ - Triterpenes \\ - Chresta scapigera/ \\ leishmanicidal activity
}

\section{INTRODUCTION}

Plants have been traditionally used for the treatment of diseases of different aethiology. Especially in the last decade, phytotherapy has received considerable attention in the search for alternatives to chemotherapy in parasitic diseases control (Muelas-Serrano et al., 2000). Many of these studies involve species of the Asteraceae family, among which can be mentioned Lychnophora granmongolense (Grael et al., 2000), Munnozia maronii (Fournet et al., 1993), Vernonia brachycalyx (OketchRabah et al., 1998), Neurolaena lobata (Berger et al., 2001), whose crude extracts and isolated compounds presented antiprotozoal activity.

Leishmaniasis is a protozoan disease and occurs widely in tropical areas in South America (Sauvain et al., 1996). According to the WHO there are 2 million new cases of leishmaniasis per year worldwide (Barata et al.,
2000). This disease is caused by haemoflagellate protozoan parasites that survive and multiply in magrophages in the mammalian host and are transmitted by phlebotomine sandflies (Salvador et al., 2002). The incidence of the disease has increased in the last years, and the therapy available mainly relies on antimonials, pentamidine and amphotericin $\mathrm{B}$, which are toxic, difficult to apply in the field and not always effective (Mafezoli et al., 2000).

Another protozoan disease is South America trypanosomiasis caused by Trypanosoma cruzi and widespread though out the subcontinent with an estimated 18 million people infected (Barata et al., 2000). In Brazil about 5-6 million people are infected, and of which 300,000 are located in São Paulo State. The population has been infected mainly by contaminated blood transfusion for the control of the insect vector (Ribeiro, Veloso, 1997). Gentian violet is the only effective chemoprophylatic agent available in blood banks. However, it is not completely accepted by 
clinicians or patients because of its undesirable effects such as coloring the skin and possible mutagenic effects (Grael et al., 2000; Coura, Castro, 2002). For the acute and chronic diseases, the treatment is still a challenge today, since the available drugs possess severe side effects and are not completely efficient (Coura, Castro, 2002).

Thus, there is an urgent need for new drugs active against Leishmania spp and Trypanosoma cruzi.

Chresta, belonging to Asteraceae family, is a small genus that comprises 12 endemic species of the "Cerrado brasileiro" (Robinson, 1999). There are no prior studies about biological activity of this genus. The present studies, crude extracts (roots, stem, leaves and inflorescences) and some compounds isolated from Chresta scapigera were evaluated for their ability to reduce viability of axenic Leishmania amazonensis amastigotes and T. cruzi trypomastigotes forms, in vitro.

\section{MATERIAL AND METHODS}

\section{Plant material}

Chresta scapigera was collected in Furnas (MGBrazil) in July, 1998, and identified by Dr. João Semir (Instituto de Biologia, Unicamp, Campinas, SP-Brazil). A voucher of each specimen is deposited in the Herbarium of FFCLRP/USP (SPFR6874).

\section{Extraction and isolation process}

Roots (188.0 g), stem (252.0 g), leaves (313.0 g) and inflorescences $(99.0 \mathrm{~g})$ were separated, dried, pulverized and stored in dark bags to protect them from humidity and light. The powdered material was extracted by maceration with $n$-hexane, dichloromethane and ethanol, respectively, at room temperature. The $n$-hexanic extract of roots $(9.521 \mathrm{~g})$ was chromatographed on a column of silica gel $60(0.063-0.200 \mathrm{~mm}$, Merck), eluted with hexane, ethyl acetate, methanol and mixtures of these solvents of increasing polarity. This extract furnishes 18 fractions and the fractions 3 and 4 were purified by preparative TLC yielding $\beta$-amyrin acetate (1) (16 mg) and $11 \alpha, 12 \alpha$-oxidetaraxeryl acetate (2) $(10 \mathrm{mg})$, respectively. The $n$-hexanic extract of inflorescences $(2.594 \mathrm{~g})$ was chromatographed in the same conditions and furnishes 14 fractions. Preparative TLC was used to purify the fractions 4 and 7 , which yield lupeol (3) $(30 \mathrm{mg})$ and its acetate (4) $(6 \mathrm{mg})$, respectively. The ethanolic crude extract of inflorescence $(2.6 \mathrm{~g})$ was partitioned between dichloromethane and methanol. The hidroalcoholic phase $(1.3 \mathrm{~g})$ was submitted to filtration on sephadex LH-20 and the fractions 6 and 7 were purified by preparative HPLC in reverse phase (column ODS Shimadzu $5 \mu \mathrm{m}, 20 \times 250 \mathrm{~mm}$, eluent: methanol:water in gradient, flow $9 \mathrm{~mL} / \mathrm{min}$, UV detection: $280 \mathrm{~nm}$ ) affording tiliroside (5) (22 $\mathrm{mg})$, apigenin (6) (12 mg) and kaempferol (7) (10 $\mathrm{mg}$ ), respectively. While the dichloromethanic phase $(391 \mathrm{mg}$ ) was chromatographed on a silica gel column eluted with hexane, ethyl acetate, methanol and mixtures of these solvents of increasing polarity. The fraction 3 was purified by preparative TLC affording crysoeriol (8) (3 mg). The ethanolic crude extract of stem was chromatographed on PVP by vacuum liquid chromatography eluted with $\mathrm{CHCl}_{3}$, methanol and mixtures of these solvents of increasing polarity. Filtration on sephadex LH-20 was used to purify the fraction 1, which yield crysoeriol (8) (3 mg), apigenin (6) $(2 \mathrm{mg})$ and luteolin (9) (3 mg).

The structures of all compounds were determined by spectroscopic methods (IR, ${ }^{1} \mathrm{H}-$ and ${ }^{13} \mathrm{C}$-NMR). All extracts and isolated compounds were evaluated against axenic $L$. amazonensis amastigotes and $T$. cruzi trypomastigotes forms, in vitro, according to a previous report (Mafezoli et al., 2000; Bastos et al., 1999).

\section{Trypanocidal activity}

For the trypanocidal activity, blood of Swiss albino mice infected with Trypanosoma cruzi (Y strain) was used, which was collected by cardiac puncture at the peak of parasitemia and was diluted to contain $10^{6}$ trypomastigotes/ $\mathrm{mL}$. Stock solutions (crude extracts) were prepared in $2.5 \%$ of dimethyl sulfoxide (DMSO) and were added to blood samples to provide a final concentration of $4000 \mu \mathrm{g} / \mathrm{mL}$. After incubation for 24 hours at $4{ }^{\circ} \mathrm{C}$, the number of parasites was determined according to Brener (1962). In the tests, gentian violet $(250 \mu \mathrm{g} / \mathrm{mL})$ was used as positive control and DMSO $2.5 \%$ as negative control. All experiments were performed in triplicate.

\section{Leishmanicidal activity}

Axenic Leishmania (L.) amazonensis (strain designation MPRO/BR/72/M 1841) amastigotes were serially cultivated at $33{ }^{\circ} \mathrm{C}$ in modified UM-54 mediun (Pral et al., 2003) and were used at the beginning of the stationary phase. Washed parasites were resuspended in RPMI-1640 medium supplemented with $4 \%$ fetal calf serum, $\mathrm{pH} 5.0$ and incubated at $33{ }^{\circ} \mathrm{C}$ for 24 hours with crude extracts $(1000 \mu \mathrm{g} / \mathrm{mL})$ dissolved previously in RPMI-1640. As controls, parasite suspensions were incubated in RPMI alone or RPMI containing $0.1 \%$ 


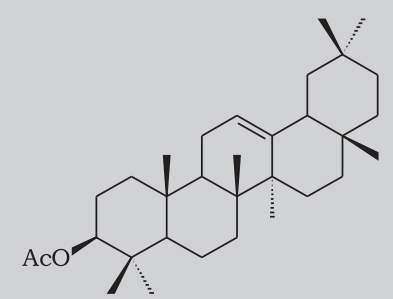

(1) $\beta$-amyrin acetate<smiles>C=C(C)C1CCC2(C)CCC3C(CCC4C3(C)CCC3C(C)(C)C(OC)CCC34C)C12</smiles>

(4) lupeol acetate<smiles>O=c1cc(-c2ccc(O)cc2)oc2cc(O)cc(O)c12</smiles>

(6) apigenin<smiles>COc1cc(-c2cc(=O)c3c(O)cc(O)cc3o2)ccc1O</smiles>

(8) crysoeriol

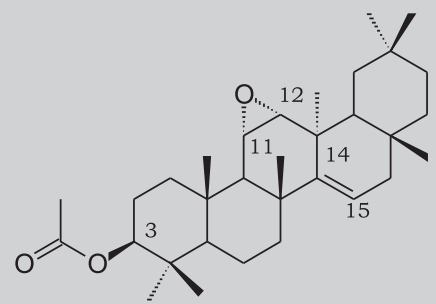

(2) $11 \alpha, 12 \alpha$-oxidetaraxeryl acetate

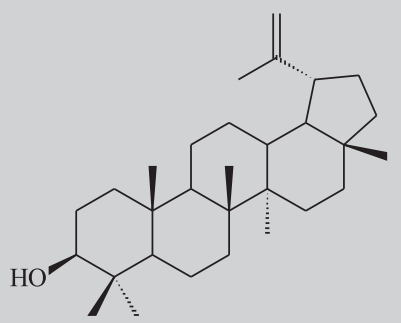

(3) lupeol<smiles>O=C(/C=C/c1ccc(O)cc1)OCCCOC(Oc1c(-c2ccc(O)cc2)oc2cc(O)cc(O)c2c1=O)C(O)CO</smiles>

(5) tiliroside<smiles>O=c1c(O)c(-c2ccc(O)cc2)oc2cc(O)cc(O)c12</smiles>

(7) kaempferol<smiles>O=c1cc(-c2ccc(O)c(O)c2)oc2cc(O)cc(O)c12</smiles>

(9) luteolin

FIGURE 1 - Structures of isolated compounds from C. scapigera.

DMSO. Amastigote viability was assessed colorimetrically by reduction of a tetrazolium salt (MTT) as described by Mosmann (1983). Amphotericin B $(20 \mu \mathrm{g} / \mathrm{mL})$ was used as the positive control and DMSO/RPMI-1640 (1:99) negative control. The experiments were carried out in triplicate. 


\section{RESULTS AND DISCUSSION}

The results are showed in Tables I and II. All the crude extracts evaluated markedly reduce the viability of $L$. amazonensis amastigotes (at $1000 \mu \mathrm{g} / \mathrm{mL}$ ), while only the extracts hexanic of inflorescence, dichloromethanic of root and ethanolic (root and stem) did not interfere appreciably with lysis percentages of $T$. cruzi trypomastigotes forms (at $4000 \mu \mathrm{g} / \mathrm{mL}$ ).

Data in Tables I and II show that effect of the evaluated compounds varies depending on the different concentrations used in the bioassay.

Compound (5) was not active against $L$. amazonensis and $T$. cruzi at the concentrations evaluated, while the compound (1) reduced the viability of $L$. amazonensis at the lower concentration used (at $14 \mu \mathrm{g} / \mathrm{mL}$ ), but not interfere with lysis percentages of $T$. cruzi trypomastigote forms. Flavonoids (6) and (9) were the most active ones when assayed at $84 \mu \mathrm{g} / \mathrm{mL}$ against $L$. amazonensis, but a slight activity was observed against $T$. cruzi.

Compound (6) presents a 5,7,4'-hydroxylation pattern and showed active since $100 \mu \mathrm{g} / \mathrm{mL}$ with $54 \%$ of lysis. Ribeiro et al. (1997) and Grael et al. (2000) have demonstrated that hydroxylated flavonoids were more active than methoxylated flavonoids when evaluated against trypomastigote forms of $T$. cruzi. The authors believed that the probable mechanism of action for this activity might be explained from drugs that are able to generate reactive oxygen species in which $T$. cruzi is susceptible.

The other compounds interfered with viability of $L$. amazonensis and T. cruzi at concentration evaluated.

The results presented can be considered promising and these extracts may represent a source of active substances against mainly amastigote forms of $L$. amazonensis.

TABELA I - In vitro leishmanial activity of crude extracts and compounds from C. sacpigera against axenic Leishmania amazonensis amastigotes

\begin{tabular}{|c|c|c|c|c|}
\hline \multirow{3}{*}{ Evaluated material } & \multicolumn{4}{|c|}{ Viability \% of axenic Leishmania amazonensis amastigotes (SD) ${ }^{\mathrm{a}}$} \\
\hline & \multicolumn{4}{|c|}{ Concentration $(\mu \mathrm{g} / \mathrm{mL})$} \\
\hline & 14 & 84 & 500 & 1000 \\
\hline hexanic extract of root & - & - & - & $0.96 \pm 0.00$ \\
\hline stem & - & - & - & $1.25 \pm 0.00$ \\
\hline leaves & - & - & - & $2.50 \pm 0.00$ \\
\hline inflorescence & - & - & - & $1.25 \pm 0.00$ \\
\hline dichloromethanic extract of root & - & - & - & $1.83 \pm 0.00$ \\
\hline stem & - & - & - & $3.08 \pm 0.00$ \\
\hline leaves & - & - & - & $0.77 \pm 0.00$ \\
\hline inflorescence & - & - & - & $3.27 \pm 0.00$ \\
\hline ethanolic extract of root & - & - & - & $2.31 \pm 0.00$ \\
\hline stem & - & - & - & $2.12 \pm 0.00$ \\
\hline leaves & - & - & - & $2.12 \pm 0.00$ \\
\hline inflorescence & - & - & - & $3.56 \pm 0.00$ \\
\hline Apigenin (6) & $87.50 \pm 0.01$ & $16.23 \pm 0.00$ & $3.09 \pm 0.00$ & - \\
\hline Tiliroside (5) & $100.00 \pm 0.00$ & $100.00 \pm 0.00$ & $67.8 \pm 0.00$ & - \\
\hline Kaempferol (7) & $30.00 \pm 0.56$ & $21.00 \pm 0.70$ & $20.00 \pm 0.17$ & - \\
\hline Crysoeriol (8) & $86.44 \pm 0.02$ & $73.10 \pm 0.01$ & $4.37 \pm 0.00$ & - \\
\hline Luteolin (9) & $60.69 \pm 0.02$ & $16.32 \pm 0.02$ & $12.87 \pm 0.00$ & - \\
\hline$\beta$-amyrin acetate (1) & $46.69 \pm 0.04$ & $36.17 \pm 0.00$ & $23.65 \pm 0.00$ & - \\
\hline $11 \alpha, 12 \alpha$-oxidetaraxeryl acetate (2) & $79.28 \pm 0.04$ & $50.16 \pm 0.01$ & $2.36 \pm 0.00$ & - \\
\hline Lupeol (3) & $90.89 \pm 0.08$ & $71.02 \pm 0.02$ & $2.36 \pm 0.00$ & - \\
\hline
\end{tabular}

Amphotericin B $(20 \mu \mathrm{g} / \mathrm{mL})^{\mathrm{b}}$

DMSO/RPMI-1640 (1:99)

$3.37 \pm 0.00$
$100.00 \pm 0.02$

a Parasite viability was determined by the MTT reduction assay; O.D. values are expressed as percent of those of untreated (negative control) \pm standard deviation; ${ }^{\mathrm{b}}$ positive control; ${ }^{\mathrm{c}}$ negative control; —: concentration did not evaluated. All experiments were run in triplicate 
TABELA II - In vitro trypanocidal activity of crude extracts and isolated compounds from C. scapigera against the trypomastigote forms of Trypanosoma cruzi

Evaluated material

Lysis $\%$ of $T$. cruzi trypomastigote $\pm(\mathrm{SD})^{\mathrm{a}}$

Concentration $(\mu \mathrm{g} / \mathrm{mL})$

\begin{tabular}{|c|c|c|c|c|}
\hline & 100 & 250 & 500 & 4000 \\
\hline hexanic extract of root & - & - & - & $62.77 \pm 2.19$ \\
\hline stem & - & - & - & $100.0 \pm 0.00$ \\
\hline leaves & - & - & - & $100.0 \pm 0.00$ \\
\hline inflorescence & - & - & - & $24.82 \pm 4.55$ \\
\hline dichloromethanic extract of root & - & - & - & $42.37 \pm 3.59$ \\
\hline stem & - & - & - & $61.86 \pm 7.62$ \\
\hline leaves & - & - & - & $92.80 \pm 2.64$ \\
\hline inflorescence & - & - & - & $77.96 \pm 6.39$ \\
\hline ethanolic extract of root & - & - & - & $36.43 \pm 2.54$ \\
\hline stem & - & - & - & $44.91 \pm 1.46$ \\
\hline leaves & - & - & - & $70.76 \pm 2.20$ \\
\hline inflorescence & - & - & - & $50.85 \pm 10.78$ \\
\hline Apigenin (6) & $54.57 \pm 1.56$ & $55.50 \pm 2.41$ & $62.46 \pm 1.28$ & - \\
\hline Luteolin (9) & $44.88 \pm 5.84$ & $52.57 \pm 8.00$ & $58.98 \pm 2.22$ & - \\
\hline Tiliroside (5) & $12.08 \pm 2.60$ & $17.08 \pm 7.53$ & $45.00 \pm 0.00$ & - \\
\hline $11 \alpha, 12 \alpha$-oxidetaraxeryl acetate (2) & $1.67 \pm 3.53$ & $17.08 \pm 0.88$ & $23.33 \pm 3.53$ & - \\
\hline$\beta$-amyrin acetate $(1)$ & $6.57 \pm 0.92$ & $20.61 \pm 2.74$ & $20.61 \pm 0.76$ & - \\
\hline lupeol acetate (4) & $41.81 \pm 5.14$ & $78.80 \pm 3.85$ & $79.40 \pm 2.09$ & - \\
\hline lupeol (3) & $6.67 \pm 3.53$ & $23.33 \pm 4.38$ & $23.75 \pm 8.19$ & - \\
\hline Gentian violet $(250 \mu \mathrm{g} / \mathrm{mL})^{b}$ & \multicolumn{4}{|c|}{$0.00 \pm 0.00$} \\
\hline $\operatorname{DMSO}(2.5 \%)^{\mathrm{c}}$ & \multicolumn{4}{|c|}{$100.00 \pm 0.00$} \\
\hline
\end{tabular}

${ }^{a}$ Results are expressed as lysis $\%$ of $T$. cruzi trypomastigote forms \pm standard deviation (SD); ${ }^{\mathrm{b}}$ positive control $\left(\mathrm{IC}_{50}=\right.$ $31 \mu \mathrm{g} / \mathrm{mL}$ ); ${ }^{\mathrm{c}}$ mice infected blood containing the same DMSO concentration used in the stocks solution (negative control) did not interfere with parasite viability; - : concentration did not evaluated. All experiments were run in triplicate.

However, further studies (in vitro and in vivo) should be accomplished in order to understand the mechanisms of action, as well as to evaluate the toxicity, looking for a clinical employment of those bioactive compounds.

\section{ACKNOWLEDGEMENTS}

We wish to thank FAPESP for the financial support and Prof. Dr. Walter Vichnewski for the collection of plant material.

\section{RESUMO}

\section{Efeito dos extratos e compostos isolados de Chresta scapigera sobre a viabilidade de Leishmania amazonensis e Trypanosoma cruzi}

O fracionamento dos extratos bioativos de Chresta scapigera proporcionou o isolamento de triterpenos e flavonóides, dentre os quais acetato de $\beta$-amirina (1), acetate de 11 $\alpha, 12$-oxidotaraxeril (2) e lupeol (3), assim como os flavonóides apigenina (6), caenferol (7), crisoeriol (8) e luteolina (9) mostraram-se ativos contra formas amastigotas de Leishmania amazonensis, enquanto, apenas os flavonóides (6), (7) e (9) apresentaram toxicidade contra as formas tripomastigotas de Trypanosoma cruzi.

UNITERMOS: Chresta scapigera/atividade tripanocida. Flavonóides. Triterpenos. Chresta scapigera/atividade leishmanicida

\section{REFERENCES}

BARATA, L.E.S.; SANTOS, L.S.; FERRI, P.H.; PHILLIPSON, J.D.; PAINE, A.; CROFT, S.L. Antileishmanial activity of neolignans from Virola species and synthetic analogues. Phytochemistry, v. 55, p. 589-595, 2000 . 
BASTOS, J.K.; ALBUQUERQUE, S.; SILVA, M.L.A. Evaluation of the trypanocidal activity of lignans isolated from leaves of Zanthoxylum naranjillo. Planta Med., v. 65 , p. 541-544, 1999.

BERGER, I.; PASSREITER, C.M.; CACERE, A.; KUBELKA, W. Antiprotozoal activity of Neurolaena lobata. Phytother. Res., v. 15, p. 327-330, 2001.

BRENER, Z. Therapeutic activity on criterion of cure on mice experimentally infected with Trypanosoma cruzi. Rev. Inst. Med. Trop. São Paulo, v. 4, p. 389-396, 1962.

COURA, J.R.; DE CASTRO, S.L. A critical review on Chagas disease chemotherapy. Mem. Inst. Oswaldo Cruz, v. 97, p. 3-24, 2002.

FOURNET, A.; MUÑOZ, V.; ROBLOT, F.; HOCQUEMILLER, R.; CAVÉ, A.; GANTIER, J.C. Antiprotozoal activity of dehydrozaluzanin $\mathrm{C}$, a sesquiterpene lactone isolated from Munnozia maronii (Asteraceae). Phytother. Res., v. 7, p. 111-115, 1993.

GRAEL, C.F.F.; VICHNEWSKI, W.; DE SOUZA, G.E.P.; LOPES, J.L.C.; ALBUQUERQUE, S.; CUNHA, R.W. A study of the trypanocidal and analgesic properties from Lychnophora granmongolense (Duarte) Semir \& Leitão Filho. Phytother. Res., v. 14, p. 203-206, 2000.

MAFEZOLI, J.; VIEIRA, J.C.; FERNANDES, J.B.; DA SILVA, M.F.G.F.; ALBUQUERQUE, S. In vitro activity of Rutaceae species against the trypomastigote form of Trypanosoma cruzi. J. Ethnopharmacol., v. 73, p. 335340, 2000.

MOSMANN, T. Rapid colorimetric assay for cellular growth and survival: application to proliferation and cytotoxicity assays. J. Imm. Method, v. 65, p. 55-63, 1983.
MUELAS-SERRANO, S.; NOGAL, J.J.; MARTINEZDÍAZ，R.A.; ESCARIO, J.A.; MARTINEZFERNANDEZ, J.R.; GÓMEZ-BARRIO, A. In vitro screening of American plant extracts on Trypanosoma cruzi and Trichomonas vaginalis. J. Ethnopharmacol., v. 71, p. 101-107, 2000.

OKETCH-RABAH, H.A.; CHRISTENSEN, S.B.; FRYDENVANG, K.; DOSSAJI, S.F.; THEANDER, T.G.; CORNETT, C.; WATKINS, W.M.; KHARAZMI, A.; LEMMICH, E. Antiprotozoal properties of 16,17dihydrobrachycalyxolide from Vernonia brachycalyx. Planta Med., v. 64, p. 559-562, 2001.

RIBEIRO, A.; VELOSO, D.P. Trypanocidal flavonoids from Trixis vauthieri. J. Nat. Prod., v. 60, p. 836-838.

ROBINSON, H. Generic and subtribal classification of American Vernonieae, Smithsonian contributions to Botany, number 89. Washington: Smithsonian Institution Press, 1999. p. 116.

SALVADOR, M.J.; FERREIRA, E.O.; PRAL, E.M.F.; ALFIERI, S.C.; ALBUQUERQUE, S.; ITO, I.Y.; DIAS, D.A. Bioactivity of crude extracts and some constituents of Blutaparon portulacoides (Amaranthaceae). Phytomedicine, v. 9, p. 566-571, 2002.

SAUVAIN, M.; POISSON, J.; KUNESCH, N.; GANTIER, J.C.; GAYRAL, P.; DEDET, J.P. Osilation of leishmanicidal triterpenes and lignans from Amazonian Liana Doliocarpus dentatus (Dilleniaceae). Phytother. Res., v. 10, p. 1-4, 1996.

Recebido para publicação em 16 de março de 2006. Aceito para publicação em 07 de março de 2007. 